Jurnal Ilmu Sosial dan Pendidikan (JISIP)

Vol. 6, No. 1 Januari 2022

e-ISSN : 2656-6753, p-ISSN: 2598-9944

DOI: 10.36312/jisip.v6i1.2803/http://ejournal.mandalanursa.org/index.php/JISIP/index

\title{
Implementasi Kebijakan Pembinaan Kesadaran Bela Negara Pada Mahasiswa Bidikmisi Universitas Pembangunan Nasional "Veteran" Jawa Timur
}

\author{
Mohammad Ifan Fanani' ${ }^{1}$, Sri Wibawani ${ }^{2}$ \\ ${ }^{1,2}$ universitas Pembangunan Nasional "Veteran" Jawa Timur
}

Article Info

Article history:

Received 05 Januari 2022

Publish 08 Januari 2022

\section{Keywords:}

Public Policy

Policy Implementation

State Defense

$P K B N$

\section{Info Artikel}

\section{Article history:}

Diterima 05 Januari 2022

Publis 08 Januari 2022

\section{Corresponding Author:}

Sri Wibawani

UPN "Veteran" Jawa Timur

Email: Wibawani2002@yahoo.com

\begin{abstract}
Fostering awareness of state defense or what is commonly called PKBN is the government's effort to create deterrence to strengthen the defense of the Unitary State of the Republic of Indonesia in the face of all opportunities and threats from within and outside the country. The East Java 'Veteran' National Development University implemented PKBN through extracurricular activities through the Student Activity Unit (UKM) so that a policy of fostering state defense awareness was formed for bidikmisi students at the East Java 'Veteran' National Development University. The purpose of this study was to determine the implementation of state defense awareness policies in bidikmisi students at the 'Veteran' National Development University in East Java. This research is a descriptive qualitative research with research focus based on Edward III's policy implementation model, namely communication, resources, disposition and bureaucratic structure. The results showed that the implementation of the policy of fostering awareness of state defense in Bidikmisi students at the National Veterans Development University of East Java could not be carried out optimally.

ABSTRACT
Pembinaan kesadaran bela negara atau yang biasa disebut PKBN merupakan upaya
pemerintah untuk mewujudkan daya tangkal untuk memperkokoh pertahanan
Negara Kesatuan Republik Indonesia dalam menghadapi segala peluang dan
ancaman dari dalam maupun luar negeri. Universitas Pembangunan Nasional
'Veteran' Jawa Timur melaksanakan PKBN melalui kegiatan ekstrakurikuler
melalui Unit Kegiatan Mahasiswa (UKM) sehingga terbentuklah suatu kebijakan
pembinaan kesadaran bela negara pada mahasiswa bidikmisi Universitas
Pembangunan Nasional 'Veteran' Jawa Timur. Tujuan dari penelitian ini adalah
untuk mengetahui implementasi kebijakan kesadaran bela negara pada mahasiswa
bidikmisi Universitas Pembangunan Nasional 'Veteran' Jawa Timur. Penelitian ini
merupakan penelitian kualitatif deskriptif dengan fokus penelitian berdasarkan
model implementasi kebijakan Edward III yaitu komunikasi, sumber daya, disposisi
dan struktur birokrasi. Hasil penelitian menunjukkan bahwa implementasi kebijakan
pembinaan kesadaran bela negara pada mahasiswa bidikmisi Universitas
Pembangunan Nasional Veteran Jawa Timur belum bisa dilaksanakan secara
optimal.
\end{abstract}

This is an open access article under the Lisensi Creative Commons AtribusiBerbagiSerupa 4.0 Internasional

(c) (i) (?)

\section{PENDAHULUAN}

Bela negara merupakan sebuah kewajiban konstitusional bagi setiap warga negara yang termaktub dalam berbagai bentuk dasar yuridis dalam suatu negara. Kewajiban bela negara termaktub dalam Undang-Undang Dasar Negara Republik Indonesia 1945 pasal 27 ayat 3 yang 
menjelaskan bahwa tiap-tiap warga negara berhak dan wajib ikut serta dalam upaya pembelaan negara. Keterlibatan warga negara dalam sistem pertahanan negara dapat terwujud dalam implementasi pendidikan bela negara yang dilaksanakan untuk mencetak kader bela negara (Pratama C. D., 2020). Pendidikan bela negara dilaksanakan sebagai wujud implementasi dari pembinaan kesadaran bela negara untuk dapat mempertahankan eksistensi Negara Kesatuan Republik Indonesia sebagai suatu negara yang berkedaulatan. Pembinaan kesadaran bela negara atau yang biasa disebut PKBN merupakan upaya pemerintah untuk mewujudkan daya tangkal untuk memperkokoh pertahanan Negara Kesatuan Republik Indonesia dalam menghadapi segala peluang dan ancaman dari dalam maupun luar negeri. Hal tersebut seperti dijelaskan pada Peraturan Menteri Pertahanan Nomor 32 Tahun 2016 yang menjelaskan PKBN ditujukan untuk membangun dan membentuk sikap mental serta karakter setiap warga negara Indonesia agar memiliki rasa cinta tanah air serta kesadaran bela berbangsa dan bernegara, setia pada Pancasila sebagai ideologi negara, rela berkorban bagi bangsa dan negara, serta memiliki kemampuan awal bela negara baik secara fisik maupun mental.

Pelaksanaan PKBN menurut Undang-Undang Nomor 23 Tahun 2019 pasal 8 ayat 1 dilaksanakan melalui sistem pendidikan yang didalamnya mencakup kurikulum wajib yang mencantumkan pendidikan kewarganegaraan, keagamaan dan bahasa dalam seluruh jenjang pendidikan mulai dari pendidikan dasar sampai dengan pendidikan tinggi. UPN "Veteran" Jawa Timur merupakan lembaga pendidikan tinggi yang menanamkan pendidikan bela negara sehingga disebut sebagai kampus bela negara yang identik dengan karakter dan jiwa bela Negara. Satu dari bentuk aktualisasi diri sebagai kampus bela negara adalah upaya UPN "Veteran" Jawa Timur untuk menciptakan mahasiswa yang berkarakter bela negara melalui berbagai program maupun kegiatan, seperti pendidikan bela negara yang merupakan mata kuliah wajib yang harus ditempuh oleh setiap mahasiswanya. Implementasi pendidikan bela negara diwujudkan dalam kegiatan pembelajaran intrakurikuler mata kuliah pembentuk kepribadian yaitu Pancasila, Pendidikan Kewarganegaraan, Bahasa Indonesia, Widya Mwat Yasa, Kegiatan Outbond Bela negara serta kegiatan Ekstrakurikuler melalui lembaga kemahasiswaan

Pembentukan mahasiswa berkarakter bela negara melalui kegiatan non akademik dapat diwujudkan dalam lembaga kemahasiswaan berbentuk unit kegiatan mahasiswa (UKM) di UPN "Veteran" Jawa Timur. UKM merupakan organisasi kemahasiswaan yang memiliki tugas merencanakan, melaksanakan dan mengembangkan kegiatan ekstrakurikuler kemahasiswaan yang bersifat penalaran dan kegemaran, kesejahteraan dan minat khusus sesuai dengan tugas dan tanggung jawabnya (Arianto, 2017). Terdapat kebijakan tentang kewajiban secara personal mahasiswa untuk mengikuti UKM di UPN "Veteran" Jawa Timur untuk mewujudkan mahasiswa pioner pembangunan yang unggul dan berkarakter bela negara. Kebijakan tersebut termuat dalam sebuah persyaratan mahasiswa baru ketika hendak masuk menjadi mahasiswa di UPN "Veteran" Jawa Timur. Dalam kebijakan pada Form.3.0/UPNJATIM/PPMB/2021 tentang surat pernyataan kesanggupan mengikuti kegiatan kemahasiswaan dijelaskan dalam poin pertama bahwa mahasiswa bersedia untuk mengikuti UKM atau Organisasi Kemahasiswaan di UPN "Veteran" Jawa Timur. pada catatan diberikan keterangan bahwa mahasiswa bidikmisi diwajibkan untuk mengikuti UKM Resimen Mahasiswa, Mahasiswa Pecinta Alam dan Pramuka atau yang biasa disebut dengan UKM bela negara.

UKM bela negara adalah unit kegiatan mahasiswa di UPN "Veteran" Jawa Timur yang dalam kegiatan dan organisasinya mencirikan nilai-nilai bela Negara. Implementasi kebijakan tentang mahasiswa bidikmisi wajib mengikuti UKM bela Negara di UPN "Veteran" Jawa Timur bisa dikatakan belum optimal. Hal ini bisa kita lihat dari rendahnya jumlah partisipasi mahasiswa bidikmisi terhadap kebijakan tersebut.

Berdasarkan observasi pendahuluan hal tersebut disebabkan karena proses komunikasi yang dirasa kurang baik karena kurangnya konsistensi dari pimpinan perguruan tinggi, selain itu sistem 
birokrasi yang kurang memadai mengakibatkan sikap dari para sasaran kebijakan mengabaikan kebijakan tersebut sehingga partisipasi dari mahasiswa bidikmisi terhadap UKM Bela Negara menjadi sangat rendah Hal ini sangat disayangkan karena sebagai kampus bela negara seharusnya bisa menjadi pioneer bagi kampus yang lain dalam hal pembinaan kesadaran bela negara pada mahasiswanya. Berdasarkan latar belakang tersebut maka peneliti akan melaksanakan penelitian yang difokuskan pada "Implementasi Pembinaan Kesadaran Bela Negara pada Mahasiswa Bidikmisi Universitas Pembangunan Nasional "Veteran” Jawa Timur.

\section{KAJAN TEORI}

\section{Kebijakan Publik}

Kebijakan menurut KBBI adalah sebuah rangkaian konsep dan asas yang menjadi garis besar dan dasar rencana dalam pelaksanaan suatu pekerjaan, kepemimpinan dan cara bertindak. Definisi kebijakan publik menurut Handoyo (2012) merupakan suatu aktivitas yang dilakukan pemerintah untuk memenuhi kebutuhan masyarakat. Sedangkan menurut Thomas R. Dye dalam Sadhana (2011;51) "public policy is whatever government choose to do or not to do". Thomas R. Dye berpendapat bahwa kebijakan publik adalah apapun yang dipilih pemerintah untuk dilakukan dan tidak dilakukan.

\section{Implementasi Kebijakan}

Menurut Tachjan (2006) implementasi kebijakan publik merupakan proses kegiatan administratif yang dilakukan setelah kebijakan ditetapkan atau disetujui. Hal ini sejalan dengan pendapat Lestari $(2018 ; 172)$ yang menjelaskan implementasi merupakan suatu proses kegiatan yang dilakukan oleh berbagai aktor sehingga pada akhirnya akan mendapatkan suatu hasil yang sesuai dengan tujuan-tujuan atau sasaran-sasaran kebijakan itu sendiri

Menurut Tachjan $(2006 ; 25)$ tujuan implementasi ialah untuk membentuk suatu hubungan yang memungkinkan tujuan-tujuan ataupun sasaran-sasaran kebijakan publik (politik) dapat diwujudkan sebagai "outcome" (hasil akhir) dari kegiatan yang dilakukan oleh pemerintah. Berikut adalah unsur-unsur implementasi kebijakan menurut Tachjan (2015) :
a. Unsur Pelaksana (Implementor)
b. Program
c. Kelompok Sasaran (Target Groups)

George Edward III dalam Yulianto (2015;54) menegaskan bahwa masalah utama administrasi publik adalah lack of attention to implementation. Edward menyarankan untuk memperhatikan empat isu pokok agar implementasi kebijakan menjadi efektif, yaitu communication, resource, disposition or attitudes, dan beureaucratic structures. Berikut adalah penjelasan empat faktor keberhasilan implementasi kebijakan tersebut :

\section{a. Komunikasi}

Komunikasi berkenaan dengan bagaimana kebijakan dikomunikasikan pada organisasi dan/atau publik. Terdapat tiga indikator yang dapat digunakan dalam mengukur faktor komunikasi yaitu transmisi, kejelasan dan konsistensi

b. Sumberdaya

Sumber daya sebagai faktor keberhasilan implementasi kebijakan berkenaan dengan ketersediaan sumber daya pendukung, khususnya sumber daya manusia. Sumber daya yang diperlukan dalam implementasi menurut Edwards III dalam Anggara (2014;252) yaitu staf, informasi, kewenangan dan fasilitas.

c. Disposisi

Disposisi diartikan sebagai sikap, kecenderungan, keinginan, atau kesepakatan para implementor untuk melaksanakan kebijakan (Sadhana,2011;205). Sahya Anggara (2014;253) menjelaskan bahwa terdapat tiga unsur utama yang mempengaruhi kemampuan dan kemauan 
aparat pelaksana untuk melaksanakan kebijakan yaitu kognisi, arahan dan tanggapan pelaksana serta intensitas respon.

d. Struktur Birokrasi

Struktur birokrasi ini mencakup aspek-aspek sebagai berikut: struktur organisasi, pembagian kewenangan, hubungan antara unit-unit organisasi yang ada dalam organisasi bersangkutan, dan hubungan organisasi dengan organisasi luar (Sadhana,2011;206).

\section{Bela Negara}

Bela negara merupakan suatu kewajiban konstitusional bagi setiap warga negara. Definisi bela negara menurut Undang-Undang Nomor 23 Tahun 2019 adalah tekad, sikap, dan perilaku serta tindakan warga negara, baik secara perseorangan maupun kolektif dalam menjaga kedaulatan negara, keutuhan wilayah, dan keselamatan bangsa dan negara yang dijiwai oleh kecintaannya kepada Negara Kesatuan Republik Indonesia yang berdasarkan Pancasila dan Undang-Undang Dasar Negara Republik Indonesia 1945 dalam menjamin kelangsungan hidup bangsa Indonesia dan Negara dari berbagai ancaman

Setiap warga negara memiliki kewajiban yang sama dalam upaya pembelaan pertahanan negara. Hal tersebut tertuang dalam pasal 27 ayat (3) Undang Undang Dasar Negara Republik Indonesia 1945 yang berbunyi: "Setiap warga negara berhak dan wajib ikut serta dalam upaya pembelaan negara". Penjabaran lebih lanjut tentang pembelaan negara tertuang dalam UndangUndang Republik Indonesia Nomor 3 Tahun 2002 tentang Pertahanan Negara Pasal 9, yang menyebutkan bahwa bela negara adalah sikap dan perilaku warga negara yang dijiwai oleh kecintaannya kepada NKRI yang berdasarkan Pancasila dan Undang-Undang Dasar (UUD) 1945 dalam menjamin keberlangsungan hidup bangsa dan negara.

\section{Pembinaan Kesadaran Bela Negara}

Kesadaran merupakan kesanggupan alamiah manusia untuk mengenal diri sendiri, karena manusia pada hakikatnya makhluk yang sadar diri, makhluk yang bisa mengambil jarak dari dirinya sendiri untuk merenungkan dirinya sendiri (Abidin,2014;18). Kesadaran bela negara telah dituangkan dalam Undang-Undang Nomor 3 Tahun 2002 yang menjelaskan bahwa upaya bela negara selain sebagai kewajiban dasar manusia, juga merupakan kehormatan bagi setiap warga negara yang dilaksanakan dengan penuh kesadaran, tanggung jawab dan rela berkorban dalam pengabdian kepada negara dan bangsa.

Dari pengertian tersebut, pada dasarnya PKBN ditujukan untuk membangun, membentuk sikap mental dan karakter seluruh warga negara Indonesia agar memiliki rasa cinta tanah air, kesadaran berbangsa dan bernegara, yakin pada Pancasila sebagai ideologi negara, rela berkorban bagi bangsa dan negara, serta memiliki kemampuan awal bela negara, baik secara psikis maupun fisik (Wira,2017). Tujuan utama Pembinaan Kesadaran Bela Negara Menurut Peraturan Menteri Pertahanan Nomor 32 Tahun 2016 adalah mengaktualisasikan nilai bela negara dan optimisme kepada setiap warga negara, demi terwujudnya kesadaran bela negara yang mendukung sistem pertahanan yang bersifat semesta

\section{METODE PENELITIAN}

Pendekatan yang digunakan dalam penelitian ini adalah pendekatan deskriptif kualitatif. Penelitian ini dilaksanakan di Universitas Pembangunan Nasional "Veteran" Jawa Timur. Adapun fokus penelitian ini didasarkan pada model implementasi kebijakan menurut Edward III tentang faktor keberhasilan implementasi kebijakan yang meliputi komunikasi, sumberdaya, disposisi dan struktur birokrasi. Pengumpulan data dalam penelitian ini dilaksanakan dengan 3 (tiga) kegiatan yaitu Observasi, Wawancara dan dokumentasi. Informan dalam penelitian ini dipilih secara sengaja melalui metode purposive sampling dan snowball sampling. Teknik analisis data menggunakan model interaktif yang dikemukakan oleh Miles dan Huberman dalam Farida $(2014 ; 173)$ yang menjelaskan bahwa analisis data model interaktif memiliki tiga komponen yaitu : 1) reduksi data, 
2) penyajian data dan 3) penarikan kesimpulan. Serta melaksanakan uji keabsahan data dalam penelitian kualitatif meliputi credibility (validitas internal), transferability (validitas eksternal), dependability (reliabilitas) dan confirmability (objektivitas).

\section{HASIL PENELITIAN DAN PEMBAHASAN}

Universitas Pembangunan Nasional "Veteran" Jawa Timur merupakan kampus yang memiliki identitas sebagai kampus bela negara sehingga dalam proses pembelajarannya dilaksanakan sesuai kurikulum yang disusun oleh UPN "Veteran" Jawa Timur yang mana kurikulum tersebut disusun dan dikembangan untuk setiap program studi sesuai dengan perkembangan ilmu pengetahuan dan teknologi yang mengacu pada Standar Nasional Pendidikan Tinggi dengan melibatkan pemangku kepentingan dan/atau instansi terkait yang dilandasi dengan nilai-nilai bela negara. Kampus bela negara merupakan implementasi dari UUD 1945 pasal 27 ayat 3 tentang kewajiban tiap warga negara untuk bela negara. Wujud bela negara yang dilaksanakan oleh UPN "Veteran" Jawa Timur adalah dengan melaksanakan pendidikan yang merupakan suatu upaya pembinaan kesadaran bela negara sesuai Undang-Undang Nomor 23 Tahun 2019 pasal 3 ayat 2 yang menjelaskan penyelenggaraan pembinaan kesadaran bela negara dilaksanakan melalui sistem pendidikan nasional. Maka dari itu, Pimpinan lembaga UPN "Veteran" Jawa Timur membuat suatu kebijakan tentang pembinaan kesadaran bela negara pada mahasiswa bidikmisi Universitas Pembangunan Nasional "Veteran" Jawa Timur yang tertuang pada Form 3.0/PPMB/UPNJATIM/2021. Pembinaan kesadaran bela negara pada mahasiswa bidikmisi UPN "Veteran" Jawa Timur dilaksanakan melalui kegiatan ektrakurikuler dalam kampus dengan mewajibkan setiap mahasiswa penerima bidikmisi UPN "Veteran" Jawa Timur untuk mengikuti kegiatan pada UKM Bela Negara yang meliputi Resimen Mahasiswa, Pramuka dan Mahapala.

Implementasi kebijakan pembinaan kesadaran bela negara pada mahasiswa bidikmisi Universitas Pembangunan Nasional "Veteran" Jawa Timur belum bisa dikatakan optimal karena jumlah partisipasi mahasiswa bidikmisi yang masih sangat rendah. Untuk lebih mengetahui terkait implementasi kebijakan tersebut, peneliti melaksanakan penelitian dengan mengukur keberhasilan implementasi kebijakan melalui 4 (empat) faktor yang mempengaruhi keberhasilan implementasi kebijakan menurut Edward III yang meliputi komunikasi, sumberdaya, disposisi dan struktur birokrasi.

Dari aspek komunikasi, kebijakan pembinaan kesadaran bela negara pada mahasiswa bidikmisi Universitas Pembangunan Nasional "Veteran" Jawa Timur telah dikomunikasikan kepada mahasiswa bidikmisi dan stakeholder. Kebijakan tersebut telah dikomunikasikan dengan para ketua UKM Bela Negara secara baik menggunakan sistem konsolidasi dan konsultasi menjelang dilaksanakannya pekan mahasiswa baru. Sayangnya proses komunikasi yang dilaksanakan pada mahasiswa bidikmisi memiliki konsistensi yang rendah karena proses komunikasi kebijakan tersebut hanya dilaksanakan satu kali ketika pekan mahasiswa baru dalam bentuk sosialisasi pada kegiatan kuliah tamu ataupun outbond mahasiswa bidikmisi. Selanjutnya kebijakan tersebut tidak dikomunikasikan kembali kepada mahasiswa bidikmisi. Tidak dilaksanakan follow up serta kurangnya penekanan dari pelaksana kebijakan mengakibatkan kebijakan tersebut tidak dipahami oleh mahasiswa bidikmisi Universitas Pembangunan Nasional "Veteran" Jawa Timur. Hal tersebut seperti dijelaskan oleh Yulianto (2015) penyaluran komunikasi yang baik akan dapat menghasilkan suatu implementasi yang baik pula. Kegiatan komunikasi kebijakan harus dilaksanakan secara baik, jelas dan konsisten agar kebijakan dapat dipahami dilaksanakan oleh sasaran kebijakan yaitu mahasiswa bidikmisi.

Dari aspek sumber daya, Kebijakan tersebut pada dasarnya memiliki sumberdaya yang mencukupi. Dari segi staf dan fasilitas kebijakan, Universitas Pembangunan Nasional "Veteran" Jawa Timur memiliki staf yang berkualitas serta memiliki fasilitas pendukung yang cukup lengkap. Hal ini dapat kita lihat dari sarana prasarana UKM Bela Negara yang sepenuhnya mendapat 
dukungan dari lembaga. Tersedianya ruang sekretariat UKM Bela Negara yang memudahkan para pengurus UKM Bela Negara menyelenggarakan kegiatan dengan rasa aman. Selain itu, dalam setiap kegiatan UKM Bela Negara selalu mendapat dukungan dari pimpinan dalam menjalankan kegiatan. Akan tetapi minimnya informasi dan kewenangan mengakibatkan kebijakan tersebut sulit untuk berkembang dan memenuhi target yang ditentukan. Sumber daya dalam implementasi kebijakan berkenaan dengan kecakapan pelaksana kebijakan publik untuk carry out kebijakan secara efektif (Yulianto,2015). Apabila terdapat sumberdaya yang belum terpenuhi akan berdampak pada keefektifan implementasi kebijakan. Kebijakan pembinaan kesadaran bela negara pada mahasiswa bidikmisi Universitas Pembangunan Nasional "Veteran" dilaksanakan dengan minimnya evaluasi dan pengolahan data dari pimpinan. Padahal dari pimpinan sudah mewajibkan mahasiswa bidikmisi untuk membuat suatu laporan pertanggungjawaban yang mana dalam laporan tersebut meliputi laporan keuangan dan juga keaktifan mahasiswa dalam kegiatan akademik maupun non akademik seperti kewajiban mahasiswa bidikmisi untuk aktif pada UKM Bela Negara, Akan tetapi dari pimpinan tidak pernah memberikan sanksi tegas bagi mahasiswa bidikmisi yang tidak memenuhi kriteria yang ditentukan seperti partisipasi mahasiswa bidikmisi terhadap UKM bela negara.

Dari aspek disposisi, kebijakan tersebut memiliki respon yang kurang baik dari beberapa pihak. Sempat terjadi penolakan dari mahasiswa bidikmisi yang mempertanyakan alasan kenapa kebijakan tersebut diterbitkan. Kebanyakan dari mahasiswa bidikmisi merasa tidak memiliki kebebasan berkreatifitas karena mereka diwajibkan untuk aktif dalam organisasi yang tidak sesuai dengan minat dan bakatnya. Menurut Sahya Anggara (2014) menjelaskan bahwa apabila sistem nilai yang mempengaruhi sikapnya berbeda dengan sistem nilai pembuat kebijakan, implementasi kebijakan tidak akan berjalan dengan efektif. Perbedaan pemahaman tersebut berdampak pada kegagalan UKM Bela Negara dalam mempertahankan anggota mereka yang mengikuti UKM Bela Negara hanya sebagai formalitas semata dan ketika mereka mengetahui bahwa tidak ada sanksi tegas bagi para pelanggar kebijakan mereka akhirnya meninggalkan UKM Bela Negara. Hal ini dikarenakan minimnya pemahaman para mahasiswa bidikmisi dan beberapa pihak terhadap maksud dan tujuan dibuatnya kebijakan tersebut.

Dari aspek struktur birokrasi, kebijakan ini memiliki dasar birokrasi yang kurang kuat karena kebijakan tersebut hanya ditulis pada persyaratan masuk, Sehingga berdampak pada sikap sasaran kebijakan yaitu mahasiswa bidikmisi. Tidak adanya SOP dan petunjuk teknis pendukung kebijakan mengakibatkan kebijakan ini tidak bisa berjalan efektif. Struktur birokrasi yang kurang jelas juga berdampak pada ketidakjelasan kewenangan pelaksana kebijakan dalam memberi sanksi tegas kepada para pelanggar kebijakan karena tidak adanya punishment and reward dalam kebijakan ini. Hal tersebut sangat disayangkan karena pada dasarnya perlu adanya Standard Operating Procedure (SOP) yang mengatur tata aliran pekerjaan di antara para pelaksana, terlebih jika pelaksanaan program melibatkan lebih dari satu institusi (Anggara,2014). Universitas Pembangunan Nasional "Veteran" Jawa Timur perlu membuat suatu kebijakan yang mendasari implementasi kebijakan secara rinci dalam bentuk buku pedoman, SOP ataupun Peraturan Petunjuk Teknis yang mengatur cara dan metode pelaksanaan kebijakan tersebut. Sehingga pelaksanaan kebijakan dapat mengimplementasikan kebijakan secara terstruktur dan terarah.

\section{KESIMPULAN}

Berdasarkan hasil penelitian dalam pembahasan dapat disimpulkan bahwa Implementasi kebijakan pembinaan kesadaran bela pada mahasiswa bidikmisi Universitas Pembangunan Nasional "Veteran" Jawa Timur belum bisa berjalan secara efektif karena kurang terpenuhinya beberapa faktor keberhasilan implementasi kebijakan sebagai berikut:

a. Dari aspek komunikasi, implementasi kebijakan pembinaan kesadaran bela negara pada mahasiswa bidikmisi Universitas Pembangunan Nasional "Veteran" Jawa Timur memiliki 
konsistensi yang sangat rendah. Sosialisasi yang hanya dilaksanakan diawal tanpa adanya follow up mengakibatkan kebijakan tersebut kurang bisa dipahami oleh mahasiswa bidikmisi.

b. Dari aspek sumberdaya, implementasi kebijakan pembinaan kesadaran bela negara pada mahasiswa bidikmisi Universitas Pembangunan Nasional "Veteran" Jawa Timur mendapat kendala karena minimnya informasi serta kewenangan dari pelaksana kebijakan. Kurangnya pengolahan data untuk mengevaluasi kegiatan berdampak pada sulit berkembangnya kebijakan tersebut

c. Dari aspek disposisi, implementasi kebijakan pembinaan kesadaran bela negara pada mahasiswa bidikmisi Universitas Pembangunan Nasional "Veteran" Jawa Timur sempat mendapat penolakan dan pertanyaan kenapa kebijakan tersebut diciptakan, hal tersebut dikarenakan kurangnya pemahaman terhadap kebijakan secara mendalam.

d. Dari aspek struktur birokrasi, implementasi kebijakan pembinaan kesadaran bela negara pada mahasiswa bidikmisi Universitas Pembangunan Nasional "Veteran" Jawa Timur mendapatkan banyak hambatan karena struktur birokrasi kebijakan yang kurang kuat. Tidak adanya SOP serta Petunjuk Teknis menyebabkan kebijakan ini sulit mengambil langkah tegas.

\section{DAFTAR PUSTAKA}

Anggara, S., Kebijakan public, Bandung: Pustaka Setia, 2014.

Ariyanto, A., Bela Negara, Banten: Badan Kesatuan Bangsa dan Politik Provinsi Banten, 2020.

Handoyo, E., Kebijakan Publik, Semarang: Widya Karya, 2012.

Hardani, Metode Penelitian Kualitatif dan Kuantitatif, Yogyakarta: CV. Pustaka Ilmu Group Yogyakarta, 2020.

Jannah, R., \& Wibawani, S., Penerapan Nilai-Nilai Cinta Tanah Air Di Kalangan Mahasiswa Universitas Pembangunan Nasional "Veteran" Jawa Timur, Dinamika Governance: Jurnal Ilmu Administrasi Negara, 8(2), 2018.

Lestari, D., Implementasi Kebijakan Pentaan, Pengelolaan, Dan Pemberdayaan Pedagang Kaki Lima (Pkl) Di Kota Salatiga, JMAN jurnal mahasiswa Administrasi negara, 2(2), 170-177, 2018.

Peraturan Menteri Pertahanan Nomor 32 Tahun 2016

Pratama C. D., Sistem Pertahanan Negara Indonesia. KOMPAS.com; Kompas.com. https://www.kompas.com/skola/read/2020/12/17/144340969/sistem-pertahanan-negaraindonesia, 2020.

Sadhana, K., Realitas Kebijakan Publik, Malang: Universitas Negeri Malang (UM), 2011.

Salim, S., Metodelogi Penelitian Kualitatif, Bandung: Citapustaka Media, 2012.

Sugiyono, Metode Penelitian Kuantitatif, Kualitatif dan R\&B, Bandung:PT Alfabet, 2016

Tahjan, Implementasi Kebijakan Publik, Bandung: AIPI, 2006.

Undang-Undang Dasar Negara Republik Indonesia 1945

Undang-Undang Nomor 23 Tahun 2019

Zainal Abidin, D. P., Buku Ajar Pendidikan Bela Negara. Surabaya, Jawa Timur Indonesia: UPN "Veteran" Jawa Timur, 2014. 